\title{
Intercultural Adaptation Strategies to Culture Shock of International Students in China: A Case Study
}

\author{
Md Shahidul Islam Fakir ${ }^{1}$ \\ ${ }^{1}$ Assistant Professor, Department of Management Studies, Jagannath University, Dhaka, Bangladesh \\ Correspondence: Md Shahidul Islam Fakir, Assistant Professor, Department of Management Studies, Jagannath \\ University, Dhaka-1100, Bangladesh. E-mail: fakir.jnuacbd@yahoo.com
}

Received: November 17, 2017

Accepted: January 10, 2018 Online Published: January 15, 2018

doi:10.5539/ijbm.v13n2p231

URL: https://doi.org/10.5539/ijbm.v13n2p231

\begin{abstract}
The purpose of this study is to explore a case on culture shock and adaptation of an international student in China during the period from September 01, 2016 to May 01, 2017. This is the self-case study research which has been analyzed from multicultural context through a 50 sample research participants. A sample questionnaire survey on 32 international students from different developing countries and two Focus Group Discussions (FGD-1 and FGD-2) with 18 Bnagladeshi PhD and Master's students in China have been conducted through online social media such as WeChat/Skype, Facebook, e-mail and/or personal contact in order to identify the forms of intercultural shock, and also to make a list of possible intercultural adaptation strategies to evaluate the best fit intercultural adaptation strategies. This study used judgmental convenience sampling technique. As psychological and social issues affect negatively the sojourner, the culture shock and adaptation curves show ups and downs trend as our heart does all the time and this is called heartbeat and again this would be sustainable. However, this proposed heartbeat model requires approval from scholars. This study identified the best fit intercultural adaptation strategies such as harmonious relationship, integration, assimilation, and separation. This study suffers from smaller sample size and shorter time period which could be covered in the future research. The findings and recommendations have positive implications to the international students those who are normally nervous and hesitated to enter into a new foreign culture to pursue higher studies for a long period of time.
\end{abstract}

Keywords: Culture shock, China, intercultural adaptation strategy, international student

Article Classification - Case Study

\section{Introduction}

\subsection{Introduction to the Research Problem}

Among the research on intercultural adaptation, U-curve and W-curve patterns are two popular models used to explain the developmental stages of intercultural adaptation. (Chen and Starosta, 2007). Lysgaard's (1955) research on 200 Norwegian fullbright scholars in USA concluded that intercultural adaptation moves through different stages which described as U-curve and studies from Chang (1973), Deutsch and Won (1963), Morris (1960), Oberg (1960), and Smalley (1963) also confirmed the U-curve movement of intercultural adaptation that comprises four stages such as honeymoon, crisis, adjustment and biculturalism periods. Gullahorn and Gullahorn (1963, 1966) extended the U-curve pattern to describe the reentry or reverse culture shock in sojourners' own cultures and also to represent readjustment to their own countries. Though Ran An (2016) pointed out in case study article about the heartbeat model and says that, "Instead of the U-curve model I think that we can use the heartbeat model to describe the Guangzhou experience and the experiences are repetitive.", this study explores that what would be the pattern of intercultural shock and adapataion in the form of heartbeat model. Actually this study extends the Ward's (1998) heartbeat model which explains that intercultural adaptation as a heartbeat which is always jumping up and down. This study also examines the different forms of intercultural shock, possible adaptation strategies, and the best fit intercultural adaptation strategies.

\subsection{Significance of the Research}

A story about intercultural adaptation of the international students has become an important theme for both academicians and social and cultural people in the recent years. The educational institutions specifically 
universities of school of international education disciplines are realizing that they should have multicultural story about cultural differences to help national and international students learn the global culture. As the researcher/author has near about ten years experiences in teaching and research and recently is pursuing his second master's degree in Guangzhou city of China, it is common to raise a research question related to culture shock in his mind. The researcher also observed the academic value of literature related to intercultural adaptation by studying the different courses in his Master's program at South China University of Technology. Actually the researcher was unable to find out the literature related to such type of self-case study except some concepts and terms of intercultural shock and adaptation strategies. Based on the literature gaps and research questions, it is high time and justified to write a practical self-case and to analyze the case for the sake of sharing new knowledge about intercultural shock and adaptation in a host culture. That is why this study examines how culture shock as a heartbeat in the intercultural adaptation process of an international student in China from Bangladesh during the sixteen biweekly units of period from September 01, 2016 to May 01, 2017. This study also addresses the best fit adapting strategies from multicultural context. Therefore, as this is real case study, it has more significance and relevancy to produce knowledge for all concerned all over the world.

\subsection{Research Objectives, and Specific Research/Case Questions}

After a thorough introduction and significance of the study and literature review, this study concluded the following research objectives and specific case or research questions:

1). To write a real case on intercultural shock and its adapting strategy by an international student in China from Bangladesh during the period from September 01, 2016 to May 01, 2017;

2). To analyze the case by examining the following research/case questions:

- How does the proportion of possible aspects of intercultural shock and adaptation happen in the mind of researcher time to time?

- How could the proportion of intercultural shock and adaptation be as like a heartbeat?

- What are the different forms of intercultural shock experienced by the international students in a host culture like China?

- What are the possible intercultural adaptation strategies taken by the sojourners in a host culture?

- How and which intercultural adaptation strategies are best fit for international students in a host culture?

3). To propose some comments and arguments for long-term intercultural adaptation in a host culture.

\section{Relevant Related Literature/Material Studied}

Oberg (1960), vividly described the symptoms of culture shock as follows: "excessive washing of the hands; excessive concern over drinking water, food, dishes, and bedding; a feeling of helplessness and a desire for dependence on long-term residents of one's own nationality; and finally, longing to be back home, to be able to have a good cup of coffee and a piece of apple pie, to walk into a fast-food restaurant, to visit one's relatives, and, in general, to talk to people who really make sense." According to Adler (1987) and Draguns (1977), "Culture shock may contribute to individual growth for some positive issues and excitements, while the sojourners may feel confusion, anxiety, depression and uncertainty which may be detrimental to the psychological growth of some sojourners". According to Furnham \& Bochner (1982), "Culture shock occurs in the social encounters, social situations, social episodes, or social transactions between sojourners and host nationals, and it is the reaction of sojourners to problems encountered in the dealings with the host members." Thomas (1985) stated that symptoms of culture shock include depression, helplessness, hostility to the host country, feelings of anxiety, overidentification with our home country, feelings of withdrawal, homesickness, loneliness, paranoid feelings, preoccupation with cleanliness, irritability, confusion, disorientation, isolation, tension, need to establish continuity, defensiveness, intolerance of ambiguity, and impatience." According to Kim (1988), "Intercultural adaptation refers broadly to the process of increasing our level of fitness to meet the demands of a new cultural environment". Entrance to a new culture is generally accompanied by culture shock (Chen and Starosta, 2007). Intercultural adaptation increases the level of fitness of sojourners to meet the demands of a new cultural environment that is generally accompanied by culture shock (Chen \& Starosta, 2007). Research by Zhou et al., (2008) focused on contemporary theoretical approaches, such as 'culture learning', 'stress and coping' and 'social identification'. 'Culture learning' focuses on social psychology of intercultural contact. The 'stress and coping' approach derives from early psychological models of the impact of life events. Therefore, during the cross-cultural contact, people perceive themselves in a much broader context, as like- 'little fish in bigger ponds'. This can lead to identity construction largely from local social interaction. Gu et al., (2010) explored the complexities of international students' in-between experiences both in terms of their maturation and human 
development and their intercultural adaptation within a different educational environment and a different culture and society. Volet \& Ang (2012) focused on cultural diversity on university campuses creates ideal social forums for inter-cultural learning. Tian \& Lowe (2013) found that parallel processes of acculturation and deculturation are the correct intercultural adaptation strategies which reveal the journey of participants from cultural innocence to a growing intercultural awareness. They conducted a case study that explores eight American students' intercultural experiences and the impacts of such experiences on individual identity during their study in a Chinese university in 2010. In their study, data come from monthly interviews and diaries that the students kept. Wang \& Hannes (2014) used photovoice method in their study which enables research participants to visually represent themselves or share lived experiences with an audience by photographing the world as they see it. Five Asian international students were recruited as research participants. They participated in an information session, two rounds of photo taking and two focus group discussions. The participants experienced academic adjustment challenges in the areas like academic activities, academic resources, languages and time management. Participants' socio-cultural adjustment was summarized into two broad themes in their study, such as cultural differences and socio-cultural adjustment strategies. Finally Wang \& Hannes (2014) found that the host culture that are relatively easy to adapt to and participants adopted an integration or assimilation acculturation strategy, while for primary cultural values and ideologies, students are more likely to adopt a separation strategy. Wu et al., (2015), found that international students deal with academic challenges, social isolation, and cultural adjustment. Specifically, academic challenges included communication with professors, classmates, and staff. The university needs to be prepared to meet students not only academically but also socially and culturally.

To the best of knowledge of the author of this study, no other similar research on intercultural adaptation strategies to culture shock of international study in China, except the above mentioned relevant related literature. An increasing number of students from Asia and Africa participate in the global educational market. Moreover, the number of international students in China is increasing rapidly, but their experiences in China remain largely unknown. However, due to the large cultural difference between Western, Asian and African countries, their adjustment is particularly challenging. As there is a lack of research exploring Asian and African international students' intercultural adaptation processes in China and to fill the literature gaps, this study explores the intercultural adaptation strategies by analyzing a case of an international student in China and by focusing the opinions from Asian and African students in China at higher studies level.

\section{Case Description/Area Descriptions}

This study explains the case by addressing a theme titled "Culture shock and adaptation as a matter of unhappiness and happiness in Chinese culture".

\subsection{Background Situation of the Case}

The researcher was enjoying study leave from a Bangladeshi public university and pursuing his second master's degree at South China University of Technology. In China, he was impressed by new professors, colleagues and others international students with extensive experiences in various sectors and industries from different countries, actually this is the story about multicultural adaptation. The researcher has gained the high level of debate and discussions in class and gained versatile knowledge visiting different places and attending at the various occasions. He has experienced a set of culture shock and cultural adjustment in the forms of unhappiness and happiness aspects respectively during the period from first week of September, 2106 to last week of April, 2017 in the new culture.

\subsection{Experiences in the Forms of Culture Shock as Unhappiness Aspects}

The researcher faced some negative issues for example in first day in Chine, he gained a bitter experience that when he arrived at the Biyuan Airport, he did not find any mineral water (Chinese Language: 'Khuan Suan Sue') and mobile SIM card to talk with the family members and after that the Chinese representative received him and he arrived in his dormitory. After that he went to a Muslim restaurant and he observed most of the customers use chop stick instead of right hand to take food and then he amazed.

Moreover, he gained a little bit bitter experience regarding the communication with Chinese while he used English language. When he visited the market places during whole day, he was unable to find a Muslim restaurant, and as a result, he passed his whole day without food and he became unhappy.

After a medium level adjustment in the new culture, suddenly the researcher faced a bitter experiences in respect of attitudes and habitual facts of other international students surrounding him. He observed the lifestyles of others and tried to link his lifestyles in China and same as in Bangladesh. He gained the number of experiences of culture shock in addition to the culture shock of food habit in China. Then, he was mentally upset and he 
faced many difficulties, for example loneliness, isolation from all family members, to stay there and to continue his study but he did not express this sadness in his life to anyone because he is man of introvert in nature.

\subsection{Experiences in the Forms of Cultural Adaptation as Happiness Aspects}

After completing all admission formalities, the researcher visited a number of market places in the Guangzhou city by using fantastic Guangzhou Metro service and wonderful transportation system. He participated and enjoyed the three orientation programs organized by South China University of Technology.

When the classes of international MBA program began, the researcher experienced a fantastic academic environment where course teachers are cordial and their class/seminar presentations are interactive and more learning-oriented with multiple and versatile knowledge involved, videos presentation, group discussion, case study discussion etc.

After that, he visited Guangzhou Municipal Public Security Bureau for his VISA extension purpose and Health Care Center of Guangdong International Travel for the purpose of getting physical examination record and gained a new experience regarding the quick health services providing system in Guangzhou.

Next, the researcher participated and experienced at day-long workshop titled "How to Use e-Library Resources Efficiently" and at the seminar titled "I Ching" - the philosophical foundation of Chinese culture.

He was extremely happy when his relatives and family members visited him with some preferred and cultural food items and other necessities.

He visited a number of firms, international organizations, tourist spots organized by the university authority as a partial fulfillment of the course works. He visited Guangzhou Radio Group (GRG) focusing on company introduction and symposium and enjoyed the wonderful Chinese culture-oriented dinner session sponsored by GRG group with Professor Li Min, PhD who was the supervisor of his master's thesis. The researcher along with all class-mates also visited Hong Kong Pumped Storage Development Co. Ltd, Conghua District, Guangzhou and the agricultural fields and agro-products production and packaging process of Guangzhou Luyin Agricultural Science and Technology Development Co. Ltd. and power generation process of Huizhou Pump-storage Power Station and surrounding wonderful and beautiful and heart-touching natural charming view with full of cloud and scenario with Professor An Ran, Dean, School of International Education, SCUT followed by wonderful Chinese culture-oriented Lunch and dinner sessions.

The researcher also visited the different market places such as Chine Mobile, Zara, H.M., Muji, LACOSTE, NIKE and other shopping malls and gained knowledge regarding market structure.

He participated at the Annual Commendation Ceremony and New Year's Party 2017 organized by School of International Education of South China University of Technology (SCUT) and enjoyed multicultural performances like dance, signing cultural songs, pop songs, modern songs, and love songs, fashion show, cross talk, rap performance, Angola dance, African dance performances before the music. This type of versatile experience has influenced him to convert him from introvert into extrovert. The researcher also visited different places, tourist spots including Great Wall, Summer Palace, and Forbidden City, Tiananmen Square etc. and different firms and participated Dissertation/Thesis defence.

Finally, the researcher completed his master's degree and returned back to the home country is continuing his public university teaching and research job.

\section{Research Methods and/or Techniques}

\subsection{Identification of Subsections}

The research is analytical and descriptive in nature. This section describing the procedures used in the study includes description of (a) sampling procedures and sample size and precision; (b) measurement approaches (including the instruments used); and (c) the research design.

\subsection{Participant (Subject) Characteristics}

Total participants of this study is 50 international students, who are from developing countries, some of them are academics and some of them are graduates and government officials. Overall, this study is done from multicultural context.

\subsection{Sampling Procedures}

Judgmental convenience sampling technique is used in this study. "Judgmental sampling is a form of convenience sampling in which the population elements are selected based on the judgment of the researchers" (Islam, 2011). 


\subsubsection{Sample Size, Power, and Precision}

Population: International students at higher studies level in Master's and $\mathrm{PhD}$ programs in South China University of Technology and other universities of China are the population of the case study.

Sample Size: From the judgment of the researcher, a convenience sample size is total 50 in which 32 international students selected from high level MBA program-2016 at School of Business Administration, South China University of Technology availing YES-China 2016 program's Chinese Government Scholarship and those who came from different developing countries of South Asia, South East Asia, Central Asia and Africa zones of the world. The another 18 Bangladeshi students have been selected as smaple those who are pursuing master's and $\mathrm{PhD}$ degree in different universities of China availing Chinese Government Scholarship for two focus group discussions (FGD)- FGD-1 consists of PhD students and FGD-2 consists of Master's students.

\subsubsection{Measures and Covariates}

Both primary and secondary data have been collected in this self-case study. Based on happiness and unhappiness in a new life-styles in China pursuing master's degree at South China University of Technology, a world-ranked university in Guangzhou city, the researcher wrote case story during the period from first week of September, 2106 to last week of April, 2017 for a sixteen biweekly units of time period.

A sample questionnaire survey on 32 international students from different developing countries and two Focus Group Discussions (FGD-1 and FGD-2) with 18 Bnagladeshi PhD and Master's students in China have been conducted through online social media such as WeChat/Skype, facebook, e-mail and/or personal contact in order to identify the forms of intercultural shock, and also to make a list of possible intercultural adaptation strategies to evaluate the best fit intercultural adaptation strategies. The survey questionnaire and FGD questions covered 10 areas of intercultural shock and its adapting strategies in a host culture (Culture shock=unhappiness and adaptation=happiness) as mentioned in the table 3 and table 4.

Focus Group Discussion Pattern: A set of focus group discussion questions has been given to each of members of FGD-1 and FGD-2, firstly all members studied the contents of the questions thoroughly and then they discussed or contacted with the researcher/author of this study on important points and gave their valuable comments on intercultural shock and its adapting strategies in a host culture which have been included in results and discussion section of this paper.

\subsubsection{Research Design}

Data Analysis and Presentation Techniques: To analyze the case, the researcher used his own knowledge and research and teaching experiences. This study used proportion chart or p-chart, weighted average method and External Factor Analysis Summary Table (EFAS Table). The table 3 and table 4 explain the details of EFAS table and also details of measurement techniques.

Moreover, this study used Microsoft Excel and Word packages. Some tables, figures have been used to make the interpretation more clear and to reduce the descriptive statements.

\section{Results and Discussion}

\subsection{The Proportion of Intercultural Shock and Adaptation Aspects}

This study assumes that the researcher experienced total 256 aspects of positive and negative issues of cultural adjustments, each biweekly period counts 16 issues. The table 1 presents the variations of happiness and unhappiness aspects up to 16th biweekly periods.

Table 1. Biweekly period-wise experiences about culture shock and its adapting strategies

\begin{tabular}{|c|c|c|c|}
\hline Sequence of Time Period in biweekly unit & $\begin{array}{l}\text { No. of } \\
\text { aspects/happiness }\end{array}$ & $\begin{array}{l}\text { No. of culture shock } \\
\text { aspects/unhappiness }\end{array}$ & Total \\
\hline Biweekly period 1 & 11 & 5 & 16 \\
\hline Biweekly period 2 & 12 & 4 & 16 \\
\hline Biweekly period 3 & 7 & 9 & 16 \\
\hline Biweekly period 4 & 10 & 6 & 16 \\
\hline Biweekly period 5 & 11 & 5 & 16 \\
\hline Biweekly period 6 & 8 & 8 & 16 \\
\hline Biweekly period 7 & 7 & 9 & 16 \\
\hline Biweekly period 8 & 4 & 12 & 16 \\
\hline
\end{tabular}




\begin{tabular}{llll}
\hline Biweekly period 9 & 15 & 1 & 16 \\
Biweekly period 10 & 14 & 2 & 16 \\
Biweekly period 11 & 11 & 5 & 16 \\
Biweekly period 12 & 10 & 6 & 16 \\
Biweekly period 13 & 12 & 4 & 16 \\
Biweekly period 14 & 11 & 5 & 16 \\
Biweekly period 15 & 13 & 3 & 16 \\
Biweekly period 16 & 13 & 3 & 16 \\
\hline
\end{tabular}

Source: Case data analysis.

As presented in the table 1 , in the 8 th biweekly period, number of unhappiness is highest (12 out of 16), on the other hand, in the 9th biweekly period, the figure is lowest ( 1 out of 16), and it means the researcher as a sojourner passed his time in a happy mood in the host culture.

Since this is an example of categorical data and the total number of culture shock and adaptation aspects is not unknown as per the assumptions of researcher, the researcher used proportion chart or p-chart. Therefore, this study uses this p-chart because the researcher was asked himself to say whether he was happy or unhappy with the host culture. The average indicates p_bar which is the central line of the chart that is the average of proportion of unhappiness and happiness aspects of cultural issues of new environment. And $n=$ number of observation (here, convenience number of observations is 16). The table 2 shows proportion of possible aspects of intercultural shock and its adaptation.

Table 2. Statistical data analysis about the proportion of possible aspects of intercultural shock and its adapting strategy

\begin{tabular}{ccccccccc}
\hline $\begin{array}{c}\text { Biweekly } \\
\text { period }\end{array}$ & $\begin{array}{c}\text { Adaptation } \\
\text { Aspects }\end{array}$ & $\begin{array}{c}\text { Culture } \\
\text { Shock } \\
\text { Aspects }\end{array}$ & $\begin{array}{c}\text { Total No. } \\
\text { of Aspects }\end{array}$ & $\begin{array}{c}\text { Proportion } \\
\text { of Culture } \\
\text { Shock }\end{array}$ & $\begin{array}{c}\text { p_bar } \\
\text { _shock }\end{array}$ & $\begin{array}{c}\text { Proportion } \\
\text { of } \\
\text { Adaptation }\end{array}$ & bar_adaptation & total of p \\
\hline 1 & 11 & 5 & 16 & 0.3125 & 0.3398 & 0.6875 & 0.6602 & 1.0000 \\
2 & 12 & 4 & 16 & 0.2500 & 0.3398 & 0.7500 & 0.6602 & 1.0000 \\
3 & 7 & 9 & 16 & 0.5625 & 0.3398 & 0.4375 & 0.6602 & 1.0000 \\
4 & 10 & 6 & 16 & 0.3750 & 0.3398 & 0.6250 & 0.6602 & 1.0000 \\
5 & 11 & 5 & 16 & 0.3125 & 0.3398 & 0.6875 & 0.6602 & 1.0000 \\
6 & 8 & 8 & 16 & 0.5000 & 0.3398 & 0.5000 & 0.6602 & 1.0000 \\
7 & 7 & 9 & 16 & 0.5625 & 0.3398 & 0.4375 & 0.6602 & 1.0000 \\
8 & 4 & 12 & 16 & 0.7500 & 0.3398 & 0.2500 & 0.6602 & 1.0000 \\
9 & 15 & 1 & 16 & 0.0625 & 0.3398 & 0.9375 & 0.6602 & 1.0000 \\
10 & 14 & 2 & 16 & 0.1250 & 0.3398 & 0.8750 & 0.6602 & 1.0000 \\
11 & 11 & 5 & 16 & 0.3125 & 0.3398 & 0.6875 & 0.6602 & 1.0000 \\
12 & 10 & 6 & 16 & 0.3750 & 0.3398 & 0.6250 & 0.6602 & 1.0000 \\
13 & 12 & 4 & 16 & 0.2500 & 0.3398 & 0.7500 & 0.6602 & 1.0000 \\
14 & 11 & 5 & 16 & 0.3125 & 0.3398 & 0.6875 & 0.6602 & 1.0000 \\
15 & 13 & 3 & 16 & 0.1875 & 0.3398 & 0.8125 & 0.6602 & 1.0000 \\
16 & 13 & 3 & 16 & 0.1875 & 0.3398 & 0.8125 & 0.6602 & 1.0000 \\
& 169 & 87 & 256 & 0.3398 & & 0.6602 & & \\
\hline
\end{tabular}

Source: Case data analysis.

As presented in the table 2, it is said that since this is an example of categorical data and the total number of culture shock and adaptation aspects is not unknown as per the assumptions of researcher, the researcher used proportion chart or $\mathrm{p}$-chart. Therefore, this study uses this $\mathrm{p}$-chart because the researcher was asked himself to 
say whether he was happy or unhappy with the host culture. The average indicates p_bar which is the central line of the chart that is the average of proportion of unhappiness and happiness aspects of cultural issues of new environment. And $\mathrm{n}=$ number of observation (here, convenience number of observations is 16).

\subsection{Intercultural Shock and Adaptation as a Heartbeat}

According to data (explained in table 1 and table 2) collected from case analysis done by the researcher/author, the figure 1 explains the nature of culture shock curve and adaptation curve which are ups and downs as our heart does all the time and this is called heartbeat.

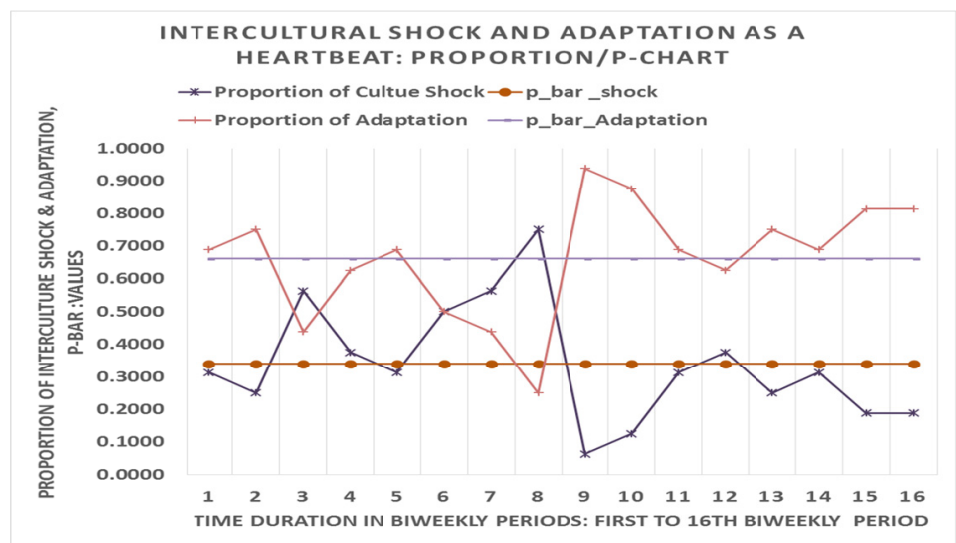

Source: Case data analysis.

Figure 1. Intercultural shock and adaptation as a heartbeat.

In the figure 1 and table 2, during the 1st biweekly period, the proportion of adaptation shows higher than proportion of culture shock and it continues up to last day of 3rd biweekly period of intercultural adaptation process and during the 3rd biweekly period it shows reverse picture i.e. adaptation level is lower than culture shock level. During the 8th biweekly period, because of personal reason, the sojourner was very upset, therefore, the culture shock and adaptation levels or curves cross the average line of culture shock and adaptation (where, p-bar_culture shock $=0.3398$ and p-bar_adaptation $=0.6602$ ). During the 9 th biweekly period, the proportion of adaptation crosses the average line of $\mathrm{p}$-bar_adaptation. Consequently, the proportion of culture shock crosses the average line of culture shock. Above all, it indicates that the adaptation process may actually have improved. During the time period from 10th to 16th biweekly period, the interactions of the sojourner with multicultural people in China indicates that the both curves of proportion of culture shock and adaptation goes in a normal way and both will reach the average line of proportion that will lead to sustainable intercultural adaptation. This study strongly argues that this situation of ups and downs and sometimes sustainable could also be continued when time period would be long from sixteen biweekly periods to sixteen months and also sixteen years, in this way, for any long period time. In fact, a model might be proposed in this context and that is Intercultural shock and adaptation as a heartbeat.

\subsection{Forms of Intercultural Shock Experienced by the International Students}

For the sake of answering the research/case question, this study explains the unhappiness issues as the forms of intercultural shock by conducting sample survey and focus group discussion. This study summarized the findings in this regard are stated below:

Food culture shock: Chinese use chop stick to take food and cooking food with limited choices of food items and spicy items.

Language shock: Unfamiliarity with new symbolic environment and misunderstanding while communicating with other class mates those who are multilingual and multicultural people with different accents of English.

Educational shock: Difficult to purchase text books.

Official documentation arrangement difficulties: More time to documentation and different office administration demanded different requirements.

Accommodation arrangement difficulties: Expensive accommodation and dormitory with sharing room.

Shopping hassles: Firstly at the very beginning of his new life in China he did not able find the required 
shopping malls.

Difficulty of performing religious activities: He did not perform important religious activities, like, the prayer of national festival of Eid-Ul-Azha last year.

Culture shock in exchanging greetings: All people including the foreign students in China use both hands while greeting and exchanging things but the sojourner uses only right hand (using right hand means more honor to others).

Difficulties with newness of places and unfamiliarity of transportation systems: Newness of places and unfamiliarity of transportation systems.

Difficulties in thesis writing and other research works: Difficulties in thesis writing and other research works.

\subsection{Possible Intercultural Adaptation Strategies}

For the sake of answering the research/case question, this study identifies the possible intercultural adaptation strategies taken by the international students/research participants of this study through conducting questionnaire sample survey and focus group discussion. This study summarized the findings in this regard are stated below:

Separation strategy for adapting food culture: Cooking own preferable and cultural food, bringing special cultural food items from own country and bringing lunch box while needed during office time.

Integration strategy for adapting language shock: Using nonverbal components like gestures with hands, head, facial expression, and mobile apps like Baidu Translate, Pleco.

Harmonious relationship strategy for adapting academic and research works, official documentation and accommodation: Global standard interactive class by showing more academic videos, analyzing more world-wide cases, completing group assignments and group discussion in a class and honorable professors extended their friendly and cooperative behaviors of encouragement, inspiration, supervision and guidance to write research papers while pursuing higher degrees. The university authority specifically the school of International Education and school of Business Administration arranged a number of company visits, study tours, orientation programs for the international students. Chinese guide and friends helped more about official documentation and about searching accommodation at a cheaper price.

Collaborative strategy for adapting shopping: Group of foreign students including the researcher went to marketplaces and enjoyed a convenience shopping.

Synergy strategy for adapting religious activities: Making friends with people from same country and same religion and bring religious cloths to perform prayer.

Integration strategy for adapting greetings: Using own custom and learning new custom and believing in global culture.

Assimilation strategy for adapting transportation services: University authority arranged company visits and study tours and using digital location map, Guangzhou metro map, MetroMan software and using smart card to pay fare.

\subsection{Best Fit Intercultural Adaptation Strategies}

The same adaptation strategies for different types of intercultural shock are not appropriate for all international students because of individual differences. Therefore, this study raises another research/case question about how and which adaptation strategies best fit from multilingual and multicultural international students' context in the host culture. Consequently, the findings of the questionnaire sample survey are presented in the table 3 , table 4 , and figure 2 . 
Table 3. External Factor Analysis Summary Table (EFAS Table) to partially decide about the best fit intercultural adaptation

\begin{tabular}{|c|c|c|c|c|c|c|c|c|c|c|c|c|}
\hline \multirow{3}{*}{$\#$} & \multirow{3}{*}{$\begin{array}{l}\text { Intercultural } \\
\text { shock and its } \\
\text { adapting } \\
\text { strategies }\end{array}$} & \multicolumn{10}{|c|}{$\begin{array}{l}\text { Total respondents/sample: } 32 \text { from developing countries, South Asian Countries: } 8 \text {, South East } \\
\text { Asian:8, Central Asian: } 8 \text { and African Countries: } 8 \text { respondents }\end{array}$} & \multirow{3}{*}{ Comments } \\
\hline & & \multicolumn{2}{|c|}{$\begin{array}{l}\text { Very } \\
\text { Important: } \\
5\end{array}$} & \multicolumn{2}{|c|}{$\begin{array}{l}\text { Somewhat } \\
\text { Important: } \\
3\end{array}$} & \multicolumn{2}{|c|}{$\begin{array}{l}\text { Not Too } \\
\text { Important: } \\
1\end{array}$} & \multirow{2}{*}{$\begin{array}{l}\begin{array}{l}\text { Total rating } \\
\text { score }\end{array} \\
\text { sum of } \\
\text { (No.*rating } \\
\text { score) }\end{array}$} & \multirow{2}{*}{$\begin{array}{l}\begin{array}{l}\text { Average } \\
\text { rating } \\
\text { score }\end{array} \\
\text { Total } \\
\text { score/32 }\end{array}$} & $\begin{array}{l}\text { Weight }(\% \\
\text { of } \% \text { of total } \\
\text { rating score })\end{array}$ & $\begin{array}{l}\text { Weighted } \\
\text { score }\end{array}$ & \\
\hline & & No. & score & No. & score & No. & score & & & $\begin{array}{l}\text { (Total rating } \\
\text { score*100/sum } \\
\text { of total rating } \\
\text { score)/100 }\end{array}$ & $\begin{array}{l}\text { Average } \\
\text { rating } \\
\text { score* } \\
\text { weight }\end{array}$ & \\
\hline 1 & 2 & 3 & 4 & 5 & 6 & 7 & 8 & 9 & 10 & 11 & 12 & 13 \\
\hline 1 & Food culture & 17 & 85 & 12 & 36 & 3 & 3 & 124 & 3.88 & 0.10 & 0.38 & \\
\hline 2 & $\begin{array}{l}\text { Language } \\
\text { culture }\end{array}$ & 22 & 110 & 8 & 24 & 2 & 2 & 136 & 4.25 & 0.11 & 0.46 & \\
\hline 3 & $\begin{array}{l}\text { Academic } \\
\text { culture }\end{array}$ & 24 & 120 & 7 & 21 & 1 & 1 & 142 & 4.44 & 0.11 & 0.50 & \\
\hline 4 & Office culture & 20 & 100 & 10 & 30 & 2 & 2 & 132 & 4.13 & 0.11 & 0.43 & \\
\hline 5 & $\begin{array}{l}\text { Accommodation } \\
\text { culture }\end{array}$ & 17 & 85 & 14 & 42 & 1 & 1 & 128 & 4.00 & 0.10 & 0.41 & \\
\hline 6 & $\begin{array}{l}\text { Shopping } \\
\text { culture }\end{array}$ & 8 & 40 & 20 & 60 & 4 & 4 & 104 & 3.25 & 0.08 & 0.27 & \\
\hline 7 & $\begin{array}{l}\text { Religious } \\
\text { culture }\end{array}$ & 16 & 80 & 11 & 33 & 5 & 5 & 118 & 3.69 & 0.09 & 0.35 & \\
\hline 8 & $\begin{array}{l}\text { Greetings } \\
\text { culture }\end{array}$ & 7 & 35 & 16 & 48 & 9 & 9 & 92 & 2.88 & 0.07 & 0.21 & \\
\hline 9 & $\begin{array}{l}\text { Transportation } \\
\text { culture }\end{array}$ & 20 & 100 & 11 & 33 & 1 & 1 & 134 & 4.19 & 0.11 & 0.45 & \\
\hline \multirow[t]{2}{*}{10} & Research works & 25 & 125 & 7 & 21 & 0 & 0 & 146 & 4.56 & 0.12 & 0.53 & \\
\hline & $\begin{array}{l}\text { Total/Overall } \\
\text { score }\end{array}$ & & & & & & & 1256 & & 1.00 & 3.99 & \\
\hline
\end{tabular}

Source: Sample survey questionnaire data analysis.

\section{Notes and Measurements}

1. List the factors or aspects of culture shock and adaptation (maximum 10 is good) in Column 2.

2. Determine individual rating score from 5.0 (very important) to 1.0 (Poor or not too important) based on the respondents' response on that factor by multiplying number of respondents with value of rating category scale, and then calculate total rating score followed by average rating score in Colum 3-10.

3. Weight each factor from 1.0 (Most Important) to 0.0 (Not Important) in Column 2, measured by calculating \% of $\%$ of total rating score (Formula: (Total rating score*100/sum of total rating score)/100) in Colum 11 . The total weights must sum to 1.00 .

4. Multiply each factor's weight times its average rating score to obtain each factor's weighted score in Column 12.

5. Use Column 13 (comments) for rationale used for each factor.

6. Add the individual weighted scores to obtain the total weighted score for the overall status of the issue in Column 12. This tells how well the situation is responding to the factors in the new environment.

Special Note on Measurement Technique: The total weighted score for an average situation or condition or intercultural adaptation is always 3.0. If the total weighted score of the case situation is more than 3:00, the situation is perfect and best fit and the adaptation strategies which carry higher average rating scores more than the total weighted score 3.99, would be regarded as the best fit adaptation strategies. By using the above described measurement technique, the weighted score for South Asian Countries, South East Asian, Central Asian and African Countries would be determined while total number of respondents would be 8 instead of 32 to 
calculate average rating score. By doing so, this study calculated the total weighted score separately for South Asian, South East Asian, Central Asian and African best fit intercultural adaptation strategies as mentioned in Table 4.

Table 4. Opinions of respondents about intercultural adaptation strategies

\begin{tabular}{|c|c|c|c|c|c|c|}
\hline \multirow{3}{*}{ \# } & \multirow{3}{*}{ Intercultural shock and its adapting strategies in a host culture } & \multicolumn{5}{|c|}{$\begin{array}{l}\text { Opinions of respondents about intercultural adaptation } \\
\text { strategies }\end{array}$} \\
\hline & & $\begin{array}{l}\text { South } \\
\text { Asian }\end{array}$ & $\begin{array}{l}\text { South } \\
\text { East Asian }\end{array}$ & $\begin{array}{l}\text { Central } \\
\text { Asian }\end{array}$ & African & Overall \\
\hline & & \multicolumn{5}{|c|}{ Average rating score } \\
\hline 1 & Food culture shock and cooking own preferable food & 3.75 & 3.50 & 4.25 & 4.00 & 3.88 \\
\hline 2 & $\begin{array}{l}\text { Language culture shock and using nonverbal components like gestures } \\
\text { and mobile apps like Baidu Translate, Pleco }\end{array}$ & 4.00 & 4.25 & 4.75 & 4.00 & 4.25 \\
\hline 3 & Academic culture shock and enjoying global standard interactive class & 4.50 & 4.50 & 4.50 & 4.25 & 4.44 \\
\hline 4 & $\begin{array}{l}\text { Official documentation arrangement difficulties and taking helps from } \\
\text { Chinese guide }\end{array}$ & 4.00 & 4.50 & 4.00 & 4.00 & 4.13 \\
\hline 5 & $\begin{array}{l}\text { Accommodation arrangement difficulties taking helps from university } \\
\text { authority }\end{array}$ & 4.50 & 3.75 & 3.75 & 4.00 & 4.00 \\
\hline 6 & $\begin{array}{l}\text { Shopping hassles and enjoying convenience shopping with group of } \\
\text { foreign students and online shopping }\end{array}$ & 3.25 & 3.50 & 3.75 & 2.50 & 3.25 \\
\hline 7 & $\begin{array}{l}\text { Difficulty of performing religious activities and making friends with } \\
\text { people from same country and same religion }\end{array}$ & 3.50 & 4.25 & 3.50 & 3.50 & 3.69 \\
\hline 8 & $\begin{array}{l}\text { Culture shock in exchanging greetings with others and using own } \\
\text { custom, learning new custom and believing in global culture }\end{array}$ & 2.75 & 3.50 & 3.25 & 2.00 & 2.88 \\
\hline 9 & $\begin{array}{l}\text { Difficulties with newness of places and unfamiliarity of transportation } \\
\text { systems and using digital location map, metro map and smart card to } \\
\text { pay fare }\end{array}$ & 4.25 & 4.75 & 4.50 & 3.25 & 4.19 \\
\hline 10 & $\begin{array}{l}\text { Difficulties in thesis writing and other research works and taking } \\
\text { encouragement, supervision and guidance from honorable professors }\end{array}$ & 4.75 & 4.50 & 4.50 & 4.50 & 4.56 \\
\hline & Total Weighted Score & $\underline{4.01}$ & $\underline{4.15}$ & $\underline{4.13}$ & $\underline{3.76}$ & 3.99 \\
\hline
\end{tabular}

Source: Sample survey questionnaire data analysis. 


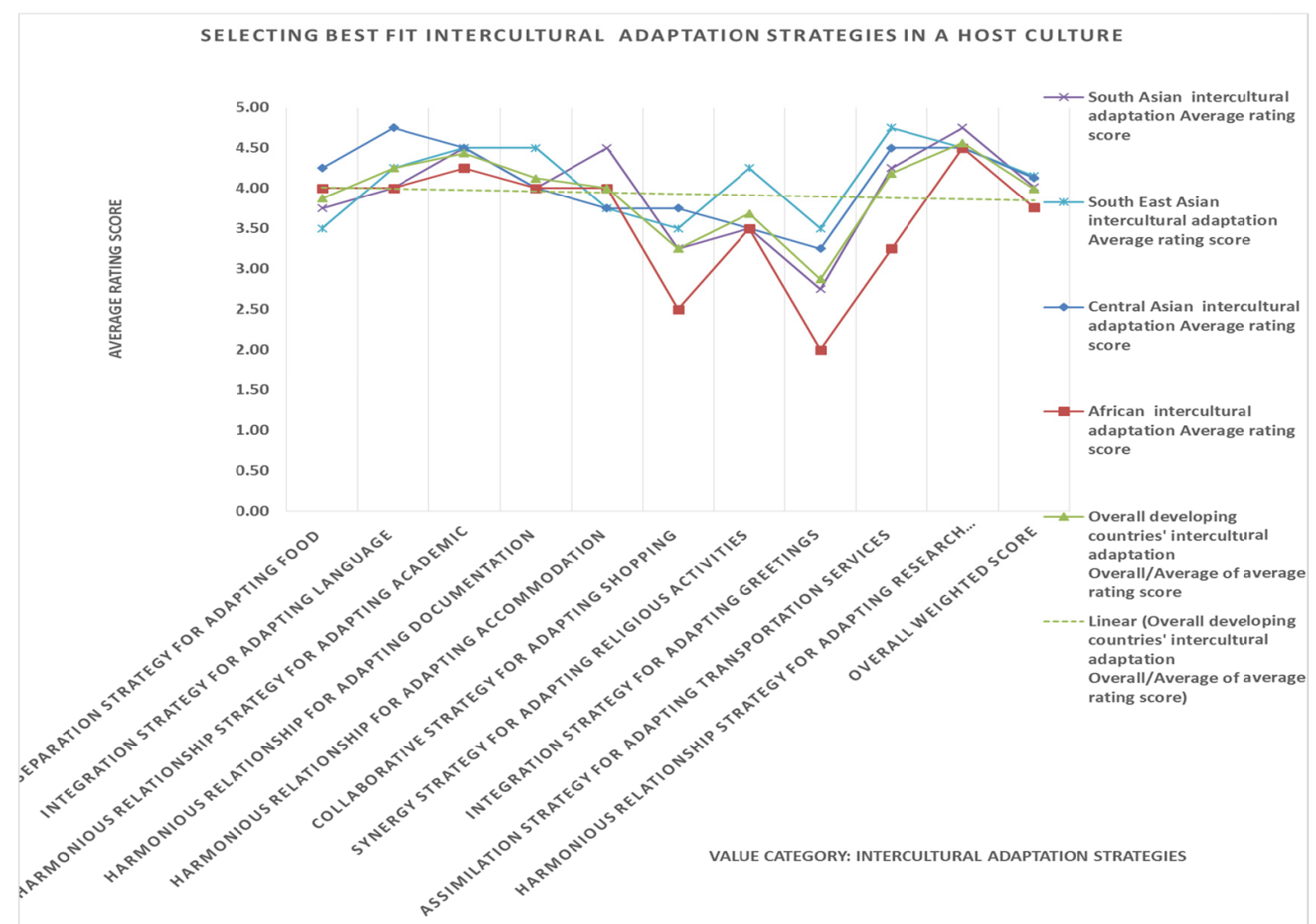

Figure 2. Selecting best fit Intercultural adaptation strategies in a host culture by average rating score and weighted score of opinions of respondents

Source: Sample survey questionnaire data analysis.

In the table 3, table 4 and figure 2, the total weighted score 3.99 has been used as a benchmark to select the best strategies. It is generally known to us that the total weighted score for an average intercultural adaptation in a host culture is always 3.0 out of 5.0. So, the total weighted score 3.99 indicates that this study results best fit intercultural adaptation for the sample sojourners. The strategies which carry higher average rating scores more than the total weighted score (3.99) would be regarded as the best fit adaptation strategies. Therefore, strategies for adapting food, shopping, religious activities and greeting culture shocks are not important elements for best fit intercultural adaptation in the host culture.

According to table 4 and figure 2, South East Asian intercultural adaptation status is highest (weighted score: 4.15) which concentrates on adaptation of language, education, documentation, religious activities, transportation and research works. However, the African intercultural adaptation status is lowest (3.76), although more than 3.00 which focuses on adaptation of food, language, education, documentation, accommodation, and research works. In between, the central Asian adaptation focuses on food adjustment.

\section{Conclusion}

This study summarizes the findings that the nature of culture shock curve and adaptation curve which are ups and downs as our heart does all the time and this is called heartbeat. For any longer period of time, the culture shock curve and adaptation curve would be ups and downs and sometimes sustainable. However, this sustainable trend may change into ups and again downs trend if any psychological and social issues will affect negatively the sojourner for adjusting the new culture. However, this proposed heartbeat model requires approval from scholars and reviewers in the field of intercultural adaptation. According to the findings of the questionnaire sample survey and focus group discussion, this study summarized that the intercultural adaptation will be sustainable and best fit, if the sojourners adopt the exact intercultural adaptation strategies as under:

- International standard research works (Harmonious);

- Education workloads (Harmonious);

- Language barriers, for example, unfamiliarity with new symbolic environment (Integration);

- Newness of places and transportation systems (Assimilation); 
- Official documentation (Harmonious);

- Accommodation (Harmonious); and finally

- Food culture shock (Separation).

In fact, the best fit intercultural adaptation strategies in the host culture are:

- Harmonious relationship;

- Integration;

- Assimilation; and

- Separation.

This study argues for the following guidelines for long-term intercultural adaptation:

- Though culture shock and adaptation go on as like our heartbeat, do not fear of new environment and try to be happy as far as possible;

- To take best intercultural adaptation strategies, for example, harmonious relationship and integration strategies for best fit in a host culture;

- To learn host culture and language;

- To make more friends in the host culture;

- To enjoy business values from online social networking media;

- To learn from intercultural shock as like learn from mistakes; and

- To be extrovert and to be a member of global culture because world is becoming one single global culture gradually.

By the way, the study suffers from smaller sample size and shorter time period which could be covered in the future research. Thus, generalizability of the findings of this study is limited. Due to the time and word limit, this study did not further report other variables, such as psychological adaptation, social adaptation, cultural background, personality, and attitude. Therefore, future studies should consider looking at other variables and this study raises a few questions:

- How does the new culture affect the sojourner to adapt and continue the study in a new culture for a long period of time?

-What would be the nature intercultural adaptation model for more than one sojourners?

- What would be the psychological and social adaptation strategies separately?

These questions are fascinating and thus left for future research. In fact, the findings, arguments for and proposed heartbeat model have positive implications to the international students those who are normally nervous and hesitated to enter into a new foreign culture to pursue higher studies for a long period of time.

\section{Acknowledgments}

The author takes the opportunity to express his deepest sense of gratitude to firstly Almighty "Allah" who enabled him to complete this research work and then his father and mother for their endless, selfless and altruistic efforts, love and wishes to success in his life. The author gratefully expresses his heartiest gratitude and indebtedness to his respected and honorable Professors at South China University of Technology for the initiation of such a study of a new dimension, scholastic idea, solitary instruction, constant encouragement, valuable comments on some research questions and constructive criticism for successful completion of the research work, analysis of data and in the preparation of this paper. The author expresses his gratitude and indebtedness to his respected colleagues, honorable senior Professors in Bangladesh and author's current colleagues from different developing countries those who were enjoying YES-China 2016 Chinese Government Scholarship as the international students of 2016 High-Level MBA program and Bangladeshi PhD and master's degree students in China availing Chinese Government Scholarship as the respondents of this research work for their valuable comments on some research questions which helped a lot in his case analysis. The author would also like to extend a million of thanks and love to his wife for her valuable suggestions, co-operation and inspiration throughout the whole tenure of his research work. All sources of external research funding in this study have been used by the author in the entire research process, from study design to submission. 


\section{References}

American Psychological Association. (1972). Ethical standards of psychologists. Washington, DC: American Psychological Association.

Adler, P. S. (1987). Culture shock and the cross-cultural learning experience. In L. F. Luce, \& E. C. Smith (Eds.), Toward internationalism (pp.14-35). Cambridge, MA.

Chen, G. M., \& Starosta, W. J. (1998). Foundations of intercultural communication (8th ed.). Shanghai, China: Shanghai Foreign Language Education Press.

Chang, H. B. (1973). Attitudes of Chinese students in the United States. Sociology and Social Research, 58, 66-77.

Deutsch, S. E., \& Won, G. Y. M. (1963). Some factors in the adjustment of foreign nationals in the United States. Journal of Social Issues, 19, 115-122.

Draguns, J. G. (1977). Problems of defining and comparing abnormal behavior across cultures. In L. L. Adler (Ed.), Issues in Cross-Cultural Research (pp. 664-675). New York: New York Academy of Science.

Furnham, A., \& Bochner, S. (1982). Social difficulty in a foreign culture: An empirical analysis of culture shock. In S. Bochner (Ed.), Culture in contact: Studies in cross-cultural interaction (pp. 161-198). New York: Pergamon.

Gu, Q., Schweisfurth, M., \& Day, C. (2010). Earning and growing in a 'foreign' context: intercultural experiences of international students. Journal of Comparative and International Education, 40(1), 7-23. https://doi.org/10.1080/03057920903115983

Islam, M. N. (2011). An introduction to research methods: A handbook for business \& health research. Dhaka: Mullick \& Brothers.

Kim, Y. Y. (1988). Communication and cross-cultural adaptation: An integrative theory. Philadelphia: Multilingual Matter.

Lysgaard, S. (1955). Adjustment in foreign society: Norwegian Fulbright grantees visiting the United States. International Social Science Bulletin, 7, 45-51.

Morris, R. T. (1960). The two-way mirror. Minneapolis: University of Minnesota Press.

Oberg, K. (1960). Culture shock: Adjustment to new cultural environments. Practical Anthropology, 7, $177-182$.

Ran, A. (2016). The case study on the multicultural classroom: Chinese and international students perspectives. China: School of International Education, SCUT.

Smalley, W. A. (1963). Culture shock, language shock, and the shock of self-discovery. Practical Anthropology, $10,49-56$.

Tian, M., \& Lowe, J. A. (2013). Intercultural Identity and Intercultural Experiences of American Students in China. Journal of Studies in International Education. Retrieved from http://journals.sagepub.com/doi/abs/10.1177/1028315313496582

Thomas, R. R. (1991). Beyond race and gender. New York: American Management Association.

Volet, S. E., \& Ang, G. (2012). Culturally mixed groups on international campuses: An opportunity for inter-cultural learning. Journal of Higher Education Research \& Development, 31(1), 21-37. https://doi.org/10.1080/07294360.2012.642838

Ward, C. (1998). The impact of value discrepancies and cultural identity on psychological and sociocultural adjustment of sojourners. International Journal of Intercultural Relations.

Wu, H., Garza, E., \& Guzman, N. (2015). International Student's Challenge and Adjustment to College. Education Research International. http://dx.doi.org/10.1155/2015/202753

Wang, Q., \& Hannes, K. (2014). Academic and socio-cultural adjustment among Asian international students in the Flemish community of Belgium: A photovoice project. International Journal of Intercultural Relations, 39, 66-81. https://doi.org/10.1016/j.ijintrel.2013.09.013

Zhou, Y., Jindal-Snape, D., Topping, K., \& Todman, J. (2008). Theoretical models of culture shock and adaptation in international students in higher education. Journal of Studies in Higher Education, 33(1), 63-75. Retrieved from http://www.tandfonline.com/doi/full/10.1080/03075070701794833 


\section{Copyrights}

Copyright for this article is retained by the author(s), with first publication rights granted to the journal.

This is an open-access article distributed under the terms and conditions of the Creative Commons Attribution license (http://creativecommons.org/licenses/by/4.0/). 